\title{
A Study of the Chinese Americans’ Dreams in Gish Jen’s Typical American
}

\begin{abstract}
ZHANG Hui
Liaocheng University, Liaocheng, China

Published in 1991, Jen’s Typical American depicts a first-generation Chinese immigrant family's pursuing their American Dream in the Post-War American society. By choosing Chinese American immigrants as her main characters and describing their struggling in the American society, Jen expresses her understanding of being Americans. In the novel, as they move from "sojourners” to American citizens, the Chang family shows different attitude towards Chinese and American cultural values. The dreams they pursue also vary. This thesis, through an analysis of the dreams the Chang family pursue in Typical American, attempts to demonstrate how the Chang family identify with their cultural identities in this process, and how they evolve from "sojourners" to "typical Americans”.
\end{abstract}

Keywords: Chinese Americans, dreams, Gish Jen, Typical American, cultural identities

\section{Introduction}

Gish Jen (1955- ), as a second generation Chinese American and a graduate of Harvard University, became famous in 1991 with the publication of her first novel Typical American which was a New York Times notable book of the year and a finalist for the National Book Critics' Circle Award. Jen explores the lives and dreams of the ethnic minorities, especially the Chinese Americans in this novel. As a recurring theme in American literature, the American Dream finds its classic expression in F. S. Fitzgerald's The Great Gatsby which was published in 1925. Nearly 70 years later, the publication of Jen's Typical American proclaims the birth of another classic description of the American Dream. However, Jen's edition of the American dream is of Chinese Americans.

The Chang families, as typical representatives of the Chinese American immigrants, do not only dream of freedom, equality, and happiness, but also dream of success, self-determination, and social acknowledgement. In the process of their pursuit of these dreams, the Changs had been struggling and wavering between traditional Chinese values and American values, and their cultural identities undergo changes from Chinese "sojourners" to "typical Americans".

\section{Dream of Success: From a Scholar to a Self-made Man}

As one of the Chinese American immigrants who come to the United States and desire to realize their dreams in this country, Ralph Chang, the protagonist in Jen's Typical American, comes to the United States with

ZHANG Hui, master, School of Foreign Languages, Liaocheng University. 
beautiful dreams cherished in his heart. He dreams of obtaining a Ph. D. degree and becoming a scholar so that he can bring honor to his family. Later, under the influence of extreme individualism, Ralph has a different understanding of success. To be a self-made millionaire becomes his new dream. The evolution of Ralph Chang's dreams brings the change of his views on success and his transformation from a Chinese to an American. This chapter, through a detailed analysis of Ralph Chang's dreams, especially the evolution of his dreams in America, attempts to illustrate how Ralph Chang changes from a Chinese to an American.

In his early days in America, Ralph cherishes his dream of obtaining a degree and becoming a scholar. However, his dream is not the American Dream. According to Adams, the "American Dream" is the "dream of a land in which life should be better and richer and fuller for everyone, with opportunity for each according to ability or achievement” (1931, p. 214). According to Adams' definition, the American Dream to a great extent signifies freedom, equality, and better life. American Dream means differently to different people. According to Cullen, "there is no one American Dream, [but] many American Dreams" (2003, p. 7). During a long period of time in the American history, Americans believe that through hard work and thrifty they can realize their American dreams. With the blossom of industrialization in modern society, the American Dream evolves into getting rich quickly by any possible means. Despite of its evolution, wealth has always been considered as a symbol of realizing the American Dream.

Ralph's dream to get his Ph. D. degree and become a scholar can be seen as his Chinese dream in America as the core value that lies behind it is Chinese Confucianism. Growing up in China, Ralph Chang bears great influence of Chinese Confucianism which values greatly the importance of education. WANG Zhu, a scholar in Song dynasty says that "Schooling is superior to ten thousands of other trades” (2003, p. 74). Influenced by such kind of thinking, Ralph makes up his mind to be a good scholar. He strives to get a Ph. D. degree as soon as possible so that he can bring honor to his whole family in China. To achieve this goal, he studies very hard on the ship to America. He also makes a detailed plan which he hopes to realize after he arrives at America. In his early days in America, Ralph is a diligent student who resolves to obtain his degree and become a scholar.

Achieving success through schooling is not only Ralph's dream but also his whole family's great expectation. As Ralph struggles to get his degree, bringing honor to his family always serves as a spiritual motive for him. The Confucian philosophy emphasizes the important role of family in one's success, which leads people to work for the honor of the family. In Ralph's eyes, his success to a great extent means a kind of repayment to his parents. At the ceremony of his graduation, Ralph can not help thinking of his parents with whom he wishes to enjoy the honor that he wins. When the school president expresses his congratulations, Ralph tells him that he wishes his father and mother were present at the ceremony.

Ralph believes that through hard work and self-discipline he can make his dream come true. He studies hard in time of difficulty. Though he momentarily loses himself in a fantasy for Cammy—secretary of Foreign Students Affairs shortly after he comes to America, Ralph returns to his study after Cammy's sudden resign. Since he carelessly forgets to renew his visa which makes him an illegal immigrant, he has to disappear from the university and changes his residence again and again to avoid being caught by the Department of Immigration. Missing the days in school, Ralph restarts his studies in his rented room during the days of hiding. He also makes great efforts to regain the opportunity to finish his Ph. D. He goes to his supervisor Professor Pinkus several times, hoping to get his help. Since Pinkus promises to write him back, Ralph checks his mailbox everyday to make sure 
that he will not miss any letters. Receiving no letters from Pinkus, Ralph even tails after Pinkus' family and hangs around his house in hope of getting his help. Fortunately, Ralph is able to go back to his university to finish his $\mathrm{Ph}$. D. since all the other Chinese students become illegal immigrants with the fall of the Kuo mintang regime in China.

Ralph's desire for success has a lot to do with his families. After his marriage, he knows that only with a Ph. D. degree he can be qualified for a teaching post in a university, and he needs a stable job to support a growing family. After Helen gets pregnant, the prospect of becoming a father motivates Ralph to struggle for his $\mathrm{Ph}$. D. and a stable professional job. "[L]ike a real father who need[s] to make a real living," Ralph knows that he must "apply himself to the doctorate on which the future of his children depend" (Jen, 1991, p. 114). With the support and encouragement of Helen and Theresa, Ralph finally manages to realize his dream of obtaining his Ph. D. degree. In Ralph's eyes, his success means a great honor to his family, and his success belongs to his whole family. In a word, during his early days in America when Ralph pursues for his Ph. D. degree, he is a diligent Chinese oversea student with Chinese values and Chinese understanding of success.

Under the influence of Grover and Professor Pierce's book, Ralph has a new dream of becoming a self-made millionaire. The Doctorate which has been so important to him seems worthy of little significance. He gives up the stable job as an associate professor and goes to business, which indicates the change of his views on success. Having identified with the American views on success, Ralph transforms from a Chinese to an American. In his "Ethnicity: Identity and Difference", Stuart Hall puts forward that cultural identity is always in "a process of identification” (HE, 1994, p. 94). In his "Cultural Identity and Diaspora”, Hall points out much more specifically that cultural identities are "points of identification, the unstable points of identification or suture, which are made through discourse of history and culture” (Cournane, 2007, p. 130). According to Stuart Hall, one's cultural identity is always in the process of changing under the influence of environment, social activities, and his acquaintances. As for Ralph, the change of his cultural identity is in accordance with the change of his values which are shaped mainly by Professor Pierce's book The Power of Positive Thinking and Grover, a Chinese American self-made millionaire.

Ralph becomes an "imagineer" after reading The Power of Positive Thinking (Jen, 1991, p.89), a gift from his new advisor Professor Pierce. After he reads this book, Ralph begins to identify with the belief that a man is what he makes up his mind to be, a common idea that advocated by Pierce's book and Grover. He treasures this book as a "divine gift" towards which he reads word by word (Jen, 1991, p.89).

As per the author's instructions, he'd written down a statement to carry in his wallet: "I can do all things through Christ which strengthened me.” He could do anything! It was a matter of faith; and of imagination, a thing Ralph had never considered before. A matter of "imagineering." He needed to picture—with faith, with all his heart—his ideal. For a man was what he made up his mind to be... He pictured himself able to do what he would. (Jen, 1991, p.88)

The meticulous way in which Ralph reads this book shows that he completely agrees with the idea advocated by the author. In merely a few days, Ralph's thinking changes a lot.

If Pierce's book facilitates the transformation of Ralph's thinking, Grover’s "preaching” directly causes the change of Ralph's views on success. Grover, a self-made millionaire, is a Chinese American born in America. In many ways, Grover is a typical American. His views on success influence Ralph greatly. Grover believes that wealth proves one's success. What Old Chao and Ralph Chang pursue- $\mathrm{Ph}$. D. and tenure professor worth 
nothing in Grover's eyes. Grover tells Ralph that there is a time that he is nobody but a "singing Chinaman" who makes a poor living by performing for the whites (Jen, 1991, p.106). Grover tells Ralph that if one does not have money in this country he is but a "singing Chinaman” (Jen, 1991, p. 106).

Brainwashed by Grover, Ralph identifies with Grover's views on success and also wants to become a self-made man. He learns from Grover that “anything is possible” in America (Jen, 1991, p. 106). After learning about Grover's experience in becoming a self-made millionaire, Ralph believes that he can also become a successful self-made man. He even immediately associates the "correct attitude" that Grover teaches him with the "positive attitude” advises by the book The Power of Positive Thinking (Jen, 1991, p. 107). Ralph even asks Grover about the first business that leads him to a millionaire. Being obsessed with the dream of becoming a millionaire, Ralph worships every word that Grover tells him as golden saying. He learns by heart the "secrets" that Grover shares with him and feels grateful to Grover for telling him so much valuable advice (Jen, 1991, p. 107). The night which Ralph spends together with Grover talking and eating can be seen as a turning point in the transformation of his thinking. From then on, Ralph's views on success change rapidly. After going back home, the idea of becoming a self-made man always haunts in his mind. “Actualize”-what Grover and Pierce’s book both stress becomes Ralph's motto (Jen, 1991, p. 113). To remind himself of this motto, Ralph "rip[s] his soft [and] gray desk blotter in half and write[s] in large red letters, ACTUALIZE” (Jen, 1991, p. 113).

In his subconsciousness, Ralph has determined to realize his American dream of becoming a self-made millionaire. The "positive thinking” which helps Ralph to recover his confidence has evolved into the belief that “every [tree] is an opportunity”, a phrase always used by Grover (Jen, 1991, p. 102). Though Ralph has got a stable job as a tenure professor over ten years of hard work, from time to time, he feels the impulse of escaping from his routine life. Once after class, on the way he drives back home, he passes a forest which makes him remember the words that Grover has told him. "Anything is possible. A man is what he makes his mind to be" (Jen, 1991, p. 186).

Not before long, Ralph puts his American dream into practice. He makes a phone call to Grover, telling him that he wants to be a self-made man. Despite that he has just got his tenure, Ralph decides to take a leave of absence and goes to business with Grover. To realize his American dream of becoming a self-made millionaire, Ralph writes a check to Grover, taking "his own wife, his own family, his job, his house, and gambling as though they were nothing to him” (Jen, 1991, p. 179). With Grover's help, Ralph takes over a fried chicken restaurant dreaming that he will become a millionaire one day.

Ralph firmly believes the importance of money in America and he even imbues the idea of money worship to his daughters. He always tells looking-for-treasure stories to the girls. He once tells them that the important thing in America is money. He informs the girls that if they have no money they are nobody but Chinamen. Compared with the days when he is still an unsophisticated student who works hard for his degree, Ralph has changed thoroughly into an American merchant who draws water to his mill.

Ralph's going to business has a lot to do with Grover and Pierce's book, but another important reason is that he wants to realize his potentials. Individualism, the core value that lies behind the American Dream, considers that one should exert his potentials to realize his personal value. The American Dream is "a dream of social order in which each man and each woman shall be able to attain to the fullest stature of which they are innately capable" (Adams, 1931, p. 214). "The fullest stature” that Adams states indicates that realizing one's fullest potentials is 
considered as one of the basic connotations of the American Dream. Before Ralph applies for the tenure professor, he has realized that he is neither interested in engineering nor teaching. He becomes aware that he is trying to fulfill his father's wish to become a scholar. After he becomes a tenure professor, he finds it unbearably boring to teach in the university. It seems that he is lost in "narrow and dead-end specialties” (Jen, 1991, p. 181). Trying to "think a way out of his predicament," Ralph chooses to go to business in hope of finding and realizing his potentials (Jen, 1991, p. 185).

Before Ralph opens the fried chicken restaurant, it is always Chinese values that pilot his behavior and thinking. However, Grover and Pierce's book makes Ralph believe that anything is possible in America only if one dares to make a try. Similar to Gatsby who "believe[s] himself omniscient-above the restrictions of society and morality" (Pearson, 1970, p. 642), Ralph believes that in America, a country with "freedom and justice for all” he can also realize his American dream and become a successful self-made man (Jen, 1991, p. 183).

Ralph's experience of realizing his dreams epitomizes the evolution of different ways of realizing the American Dream in history. In the colonial period, Americans believed that they could realize their American dreams through hard work, thrift, and strong determination. The early settlers dreamt to get rich in this new land. Many of them attempted to achieve economic independence and an improvement of social status through getting rich. They tended to realize their American dreams through hard work and thrift. Benjamin Franklin is such an example. Rising from obscurity, he achieved success in fame and wealth through hard work and strong determination.

The blossom of the industrialization in 19th century disintegrates the ideal of realizing the American Dream through hard work and diligence. Instant wealth becomes the symbol of the American Dream. Americans no longer believe that thrift and hard work will lead them to success. American Dream evolves into a pure pursuit of materialistic success by any possible even illegal means. Gatsby’s personal experience just reflects the shift from "rags to riches" to "get rich quick". Young Gatsby is a self-disciplined man who believes that hard work will bring him wealth and chance to ascend into the upper class. However, the innocent dream of young Gatsby becomes eroded as he grows up. Influenced by the ethos of his time which advocates getting rich quickly, Gatsby resorts to illegal business. He becomes a bootlegger who "s[ells] grain alcohol over the counter" in the side-street drug stores that he buys up in New York and Chicago (Fitzgerald, 1992, p. 141).

Ralph's experience is similar to Gatsby. When he first arrives in America, Ralph believes that through hard work and self-discipline he can obtain his degree and becomes a successful scholar. However, under the influence of Pierce's book and Grover, a representative of extreme individualism, Ralph's views on success change thoroughly. To pay less tax and accumulate wealth quickly, Ralph becomes a tax dodger. He spends an hour or so in his office every night replacing the tape for the day with a new one. The languishment of Ralph's Ph. D. diploma under the box of cash register tapes symbolizes that Ralph's dream of becoming a scholar has been completely replaced by the dream of becoming a millionaire. Chinese dream has been replaced by the American Dream, and Chinese values have been replaced by the American values. Ralph has transformed from "a traditional intellectual to an opportunistic merchant” in the pursuit of his American dream (CHENG, 2003, p. 310).

Ralph's going to business reflects his extreme individualistic idea. As if being thoroughly remolded, Ralph becomes "the most fervent sort of convert" (Jen, 1991, p. 195). He reads lots of books on making money and posts many "inspirational quotes” on the walls of his office (Jen, 1991, p. 198). 
ALL RICHES BEGIN IN AN IDEA.

WHAT YOU CAN CONCEIVE, YOU CAN ACHIEVE.

DON'T WAIT FOR YOUR SHIP TO COME IN, SWIM OUT TO IN.

FOLLOW THE HERD, YOU END UP A COW.

YOU CAN NEVER HAVE RICHES IN GREAT QUANTITY UNLESS YOU WORK YOURSELF INTO A WHITE HEAT OF DESIRE FOR MONEY. (Jen, 1991, p. 199)

These inspirational quotes convey the same idea that Grover and Pierce's book advocates. They both highlight the extreme power of individuals and the importance of "positive attitude" on one's way to success (Jen, 1991, p. 107). These ideas are in accordance with extreme individualism which encourages people to realize their individuality by any possible means. Ralph's worshipping of these inspirational quotes indicates his internalization of the extreme individualism.

Ralph is so anxious to realize his dream of becoming a millionaire that he easily drops into the trap of Grover who sells the unbuildable land to him. Ralph realizes too late that Grover has never intended to help him. It is but Grover's trick to get close to Helen and win her love by ostensibly helping Ralph. The unstable groundsill on which Ralph builds his restaurant symbolizes the unstable basis on which Ralph builds his American dream. In CAI's opinion, Ralph is doomed to fail as he places his ideal on the American dream that belongs to the white Americans while he is in a marginalized position of American society as an immigrant. Like Gatsby who is "a victim of his own warped idealism and false set of values" (Pearson, 1970, p. 645), Ralph is also a victim of his own idealization of America and illusion of the American Dream. He over-optimistically considers America as a paradise where he believes he can realize his American dream easily. He fails to foresee the risks that may come along in the pursuit of his dream.

After the failure of his business, Ralph wakes up from his idealization of America and illusion of the American Dream. He has to face a series of misfortune that comes along in the pursuit of his dream. The fried chicken restaurant into which he bestows all of his money and hope finally goes to bankruptcy. He is so absorbed in his business that he neglects to care for Helen, which causes her estrangement from him and having an affair with Grover. Ralph sadly finds that "his Helen, the real Helen ha[s] moved away" (Jen, 1991, p. 236). To stick to his American dream, he ignores Theresa's sincere advice and does not accept her relationship with Old Chao. The once harmonious family falls apart. Ralph finally becomes aware that pursuing the American dream helps him realize his personal value, but at the same time it may bring along many unexpected tragedies. The myth of America as a paradise collapses. Ralph realizes that freedom has its limits in America and he is not the man that he makes up his mind to be. “A man [i]s the sum of his limits” (Jen, 1991, p. 296).

Having a much realistic vision of the American Dream and the American society, Ralph finally realizes that as an American he has the chance to realize his personal values by pursuing the American Dream, but he can not escape from the tragedies and risks that may come along with the Dream. The predicament that Ralph meets with in the pursuit of his dream reflects the complexity of the American Dream (LI, 2003, p. 25). Jen has said in an interview that, "I can say that the American dream is much more complicated... I think I'm just trying to capture some of that complexity" (University of Minnesota-Driven to Discover, n.d.). The equal opportunity that American Dream claims is not attainable to the ethnic minorities as to the whites. It is much difficult for the 
ethnic minorities to realize their American Dream. Ralph also realizes that the illusion of his life "going up, up, up” before his restaurant goes bankruptcy is false (Jen, 1991, p. 236). He becomes aware that there is nothing wrong for him to cherish some of the traditional Chinese values in America. He learns from his experience that family is the most valuable treasure in this world.

After his dream of becoming a millionaire turns out to be a complete failure, Ralph indulges himself into the meditation about the question of his identity. He is confronted with the identity crisis.

Who was he? It was years before Ralph even knew to ask himself those questions; and then it was only to find that he didn't know their answers - that his own nature eluded his grasp, like a solid sublimating straightway, from between his fingers, to gas. (Jen, 1991, p. 177)

In another interview, Jen has said that "[the Changs] wonder about their identity: They ask themselves who they are, who they are becoming. And therefore, they are American” (Matsukawa, 1993, p. 115). In Jen’s opinion, always questioning "who I am” is one of the common characteristics of all the Americans. One of Jen's intentions of writing Typical American is to evoke the readers' thinking about the essence of American identity, one striking characteristic of which is the identity crisis that Ralph meets with the disillusion of his American dream. Experiencing the identity crisis, Ralph has a better understanding of the meanings of being Americans.

\section{Dream of Self-determination: From Obedient Follower to Independent Self-determiner}

Helen Chang and Theresa Chang, the two main female characters in Typical American, immigrated into the United States of America around 1940s. Both growing up in prestigious families that belong to the upper class in China, Helen and Theresa receive very strict family education which teaches them to be obedient to their parents and future husbands. As a result, both Helen and Theresa consider it natural to follow their parents' arrangements of their life. However, after immigrating into America, Helen and Theresa become more and more independent because of the change of life and the influence of American culture. Through a detailed analysis of the change of the lives and dreams of Helen and Theresa, this chapter attempts to illustrate that Helen and Theresa grow from obedient Chinese women to independent Americans.

When Helen and Theresa are in China, they always depend on the others, especially their family members. It is impossible for them to be independent economically at that time because there is no opportunity for women to go out looking for jobs. Getting married becomes their only way out. Thus, getting married with someone who can provide them good life, at least means of survival, becomes a common dream for Theresa and Helen. Theresa receives some western education in a convent school where she learns playing baseball and biology, both of which her mother considers improper for a girl to learn. Theresa's mother actually worries that too much western education may make it difficult to find Theresa a husband. To modify her too casual gait — a result of playing baseball, Theresa is sent by her mother to attend dance lessons. In her heart, Theresa desires to be a girl like her younger sister who is liked by everyone and luckily engaged with a rich, "gentle, handsome and intelligent" man (Jen, 1991, p. 48).

Helen's dream is that one day she will marry a man who treats her nicely. Having poor health in her childhood, Helen is the centre and pastime of her whole family in China. She is cared by everyone of her family even her younger sisters and brothers. Being used to the meticulous care and love of her family, Helen even wishes that she would stay forever at home, but she knows that she will eventually "have to marry and go live 
with in-laws” (Jen, 1991, p. 62). It frightens her greatly to learn the awful stories about girls who are treated badly by their in-law parents. She expects her parents to find her a nice husband who provides a guarantee for her future life.

Influenced by Chinese Confucianism, Helen and Theresa are very obedient women who habitually follow the others' especially their parents' arrangements. They have no freedom in choosing husbands for themselves and have to obey their parents' arrangements for them. Both Helen and Theresa grow up under the influence of Confucianism which lays out a series of regulations for women to obey such as "three obediences and four virtues". "Three obediences” requires that a woman obey her father as a daughter before getting married; obey her husband as a wife after marriage; and obey her son in widowhood. "Four virtues" demands that women should possess the virtue of morality, proper speech, modest manner, and diligent work. Imbued with such patriarchal thinking since their childhood, women like Helen and Theresa has internalized these doctrines into their own values system. They take it for granted that their parents would make arrangements for their life and they should unconditionally obey. They expect their parents to find husbands for them. Even after Helen loses touch with her parents after she goes to America, she still considers it important to do what her parents wish her to do. She marries Ralph mainly because she considers this marriage as the wish of her parents in China. "How right it all did seem! That Ralph should marry her, friend of Theresa - it was just as their parents would have had it" (Jen, 1991, p. 64). Theresa experiences two blind dates which are supposed to bring her into marriage. In China, following her mother's arrangement, Theresa dates with a banker's son with whom she is supposed to get married. Later in America, Theresa meets with Grover at a dinner purposely arranged by Helen and Janis.

Helen and Theresa are still Chinese obedient women in their early days in America as their views on marriage greatly reflect the influence of Chinese Confucianism. They behave passively though they dream of good husbands. They habitually consider their parents' opinions and seldom have their own desires. However, with the change of their lives in America, Helen and Theresa gradually have their own desires and dreams. In the pursuit of their dreams, they gradually accept some American values which bring the change of their views on marriage. They gradually become independent American women.

Getting a medical Ph. D. and becoming a doctor in America, Theresa no longer considers marriage as a guarantee of her life. With decent income, Theresa becomes economically independent. Having been rejected by two men, Theresa more or less has lost confidence in finding a husband. Influenced by the American Dream which encourages people to realize their potential, Theresa devotes her whole energy in study and work. To "realize her potential and individuality", Theresa makes great efforts and succeeds in becoming a career woman who makes a living by herself (GUAN, 2006, p. 73). However, it is not Theresa's wish to remain single. She has to work hard to make herself tired enough to forget the truth that she is still a spinster. She even feels that each of the hangers in her closet is a spinster who "wait[s] too patiently [and] neatly" with their "twisted throats and bent heads” (Jen, 1991, p. 141). In her spare time, the bitter loneliness tortures her greatly. In her subconsciousness, Theresa dreams to have someone who can share her thinking, happiness, and bitterness.

Theresa's independence and modesty wins Old Chao's trust and she establishes a sincere relationship with him. Theresa's relationship with Old Chao is more a kind of companionship. She does not mind whether Old Chao will marry her. There has been a time that she would rather reconcile with Janis in sharing Old Chao's love. Theresa is not greedy. She does not expect Old Chao to buy her a house or support her. What she desires most is 
his companionship, trust, and respect. As for Old Chao, Theresa is "a doctor for his many ailments, both those he could name and those he could not” (Jen, 1991, p. 173). GUAN believes that Theresa sacrifices herself to be Old Chao's lover so as to help Ralph get his Ph. D. smoothly. Theresa certainly worries if Ralph can achieve his Ph. D. degree. When she and Old Chao go dinner together, the things that they talk about always concern about Ralph's career. However, Theresa does not accept Old Chao's love for Ralph's sake. The reason that Theresa accepts Old Chao is because she feels happy and relaxed when they are together. Their relationship is based on their mutual trust and respect.

Out in the backyard, [Old Chao] planted strawberries with Theresa, it was true; also he grilled fish with her, and argued. Sometimes they ignored each other, sometimes played catch. Certainly he had never been so playful. But what Helen noticed most of all was something else, a small thing — that Old Chao did not monitor Theresa. (Jen, 1991, p. 267)

Theresa's acceptance of her extramarital relationship with Old Chao indicates that she breaks away from the restrictions of "three obediences" and "four virtues". She has become an independent woman who bravely pursues her happiness. Theresa goes through a series of inner conflicts before she accepts her relationship with Old Chao. At first, she dares not to tell Ralph and Helen her affair with Old Chao. She knows that having relationship with a married man is despised by many Chinese. She even feels ashamed of herself sometimes. When Theresa is having medical practice in the hospital, male doctors like to flirt with her. At first, Theresa always feels embarrassed, however, later she feels grateful to these married man as their behavior proves to be helpful but not harmful. She gradually considers it right to pursue her happiness and accepts her relationship with Old Chao. Though she is misunderstood by Ralph who calls her "a rotten egg” in front of her niece (Jen, 1991, p. 268), Theresa herself no longer feels ashamed of herself. She knows that she has the right to pursue her happiness.

Helen also grows from a delicate, dependent woman into an independent housewife who capably takes care of her whole family. Helen's life ambition was to "stay home forever" before she immigrated into America (Jen, 1991, p. 61). After getting married with Ralph, Helen tries her best to get accustomed to their married life. She changes from a spoiled girl to an independent housewife who is able to shoulder almost all the housework.

The same girl who had never so much as drawn her own bath was now sprouting mung beans in jars with holes punched in their screw lids... She made her own Chinese pancakes now. She made her own red bean paste, boiling and mashing and frying the beans, then using them to fill buns, which she made also. She made curtains; she made bedspreads; she rewired Ralph's old lamp. (Jen, 1991, p. 76)

What's more, Helen successfully solves several problems that she meets with in their daily life. She tries her best to make their shabby apartment as tidy as possible, craftily hiding the crack on the wall by combining several of their furniture into a "wall unit" which she learns from the American magazines (Jen, 1991, p. 66). With the instruction manual, Helen fixes the furnace which provides heat for their apartment.

Helen has her own dreams after she reads many American magazines. First, she desires for a big house. To idle away her loneliness when Theresa and Ralph are not at home, Helen cultivates a secret habit of listening to the radio and reading the magazines she keeps under her mattress. She especially "love[s] the advertisements" on the radio or in the magazines which greatly stimulate her desire to consume (Jen, 1991, p. 77). After Ralph gets his driver's license, he once takes the whole family to Connecticut. Intoxicated with the beauty of that place, the whole family especially Helen can not help dreaming that one day they will live in a big and beautiful house there. 
Helen becomes so enthusiastic about her dream to buy a new house that she masters a great deal of architecture terms which even amazes Ralph and Theresa. Actually, Helen's familiarity with these terms implies that she spends much time in researching the advertisements on architecture though she modestly says that she is just “picking it up” (Jen, 1991, p. 137). After the dream of owning a split-level house finally comes true, Helen finds that the family is full of unprecedented happiness and laughter; it seems that the new house brings life to the whole family. Helen "notice[s] smells" for the first time in her life and her relationship with Ralph also seems to have "turned so loverlike after so many years" (Jen, 1991, pp. 160-61).

Feeling nostalgic for the days when she was at home in China when everyone treated her with love and tenderness, Helen also desires for love and attention from Ralph. However, she gets more command and order from Ralph rather than love and care. Despite of Helen's efforts to join in their family conversation, Ralph always interruptes her when she is talking, complaining that her voice is too low to hear. As a man influenced greatly by Chinese patriarchal culture, Ralph believes that at home the husband would command and the wife should obey. Though Helen willingly plays the role of an obedient wife, Ralph does not feel contented. Troubled by Helen's way of breathing which he finds abnormal, Ralph tries to teach her to breathe in the right way. However, Helen breathes the same as before, which greatly irritates Ralph.

Ralph knocked at Helen's skull. “Nothing to say? Anybody there? Come on, open up.” Knocking made Ralph feel fierce, but it made Helen go blank — which made him knock more, and command her to breathe, and accuse her of holding her breath on purpose (which she wasn't, really, she wasn't, she wasn't) until she ran away into another room. (Jen, 1991, p. 73)

Helen's breathing problem symbolizes that she feels suppressed under the influence of Ralph's patriarchal behavior. It is only in front of Ralph that Helen can not breathe as freely as she wants. Sometimes being alone at home, Helen calls some of her former classmates from the English language school after finishing housework. Strangely, on the phone she finds that she is able to breathe as freely as she can. Later when she has an affair with Grover, Helen hears her breathing "so loud in her ears [that] the house seemed to resound with it” (Jen, 1991, p. 213).

Helen's affair with Grover reflects her desire of romance, which is also an outcome of the influence of the American media. Helen wishes that she would live like the heroine in the magazine who happily enjoys romantic love. Helen first appears in this novel as a girl "hum[ming] western love songs to herself" which implies her anticipation of sweet and romantic love (Jen, 1991, p. 5). In the dinner at Old Chao's home, Grover's unscrupulous winking at Helen makes her feel like the heroine in the magazine.

Still she saw herself as though in a magazine. A lady again after all, and more — she saw herself wildly in love. He lived for her, only for her. And in her dreams, she lived for him too, this man her parents would never have picked. (Jen, 1991, p. 116)

When Grover pays court to Helen with his surprising love tricks, Helen finds it hard to resist him and walks step by step into his trap. Grover, a fifth-generation Chinese American, knows how to please women like Helen. He fills Helen's apron pockets full of sugar and draws a heart with pencil on the sole of her shoe. He sends flowers to Helen, which makes "her heart flooded” (Jen, 1991, p. 216). Grover's romance and meticulous care for her make Helen feel like the heroine in the magazines. The influence of America media enables Helen to find 
her own desires. She chooses to follow but not to conceal her desires. She has changed from an obedient Chinese woman who does not have any desires into an independent American housewife who values her own desires.

Helen and Theresa become Americanized in many ways, and their dreams undergo great changes after they immigrate into America, but they still keep the Chinese ideal of family harmony and bravely uphold their responsibilities in time of difficulties. Despite of the change of Helen's cultural values, she still considers family as a kind of responsibility. She knows that Ralph and her two daughters are still the most important things that she values. She finds it easy "to forget many things in Grover's arms, but not the children" who are "so impressionable” (Jen, 1991, p. 217). Sometimes, she can not concentrate herself when she is together with Grover as she can not help worrying about her two daughters. She is sure that she will never leave Ralph and her two daughters. Gradually seeing clearly Grover's true characteristics, Helen becomes aware that he is not the man worthy of her love, so she resolutely ends up her relationship with him.

Theresa considers it her duty to offer help when the other family members are in difficulties. She comes back to help when Ralph's fried chicken restaurant goes bankruptcy and the whole family is trapped in financial crisis, forgiving Ralph's ever rudeness and cruelness to her.

It was her duty, she told herself. She was in many ways Americanized, but in this respect she was Chinese still—when family marched, she fell in step. And wasn't this what she'd longed for? Reunification, that Chinese ideal, she could not eat an orange without reciting to herself, as she did at New Year's, quan jia tuan yuan-the whole family together. (Jen, 1991, p. 265)

Helen grows from a passive woman who always follows the others' will to an active and strong woman who upholds her responsibility bravely. Helen's initiative putting an end to her relationship with Grover indicates that she becomes a woman with self-determination. She no longer follows the others' arrangements but makes decisions for herself. Initially, Helen plays a passive role in her affair with Grover as gradually seduced by him. After she learns about Grover's trick, Helen resolutely chases Grover out of her family. Helen becomes a woman who masters her own destiny. She undergoes a series of inner conflicts before making her decision in ending her relationship with Grover, but she is clear of her responsibility as Ralph's wife and the mother of two children. Helen's determination in shouldering her responsibility enables her to leave Grover resolutely. Helen also grows to a strong woman who keeps composed in time of difficulties. She always actively thinks out solutions to problems. She offers to go as a cashier when their fried chicken restaurant has financial problems. After the bankruptcy of the restaurant, she goes out looking for jobs regardless of the discrimination against women especially Chinese women. Helen also pleads Old Chao to help Ralph to go back to his university to teach.

Under the influence of American cultural values, Helen and Theresa have shaken off the spiritual fetters of "three obediences" and "four virtues". They used to be obedient Chinese women who seldom have their own desires. However, with the change of their lives in America, Helen and Theresa gradually have their own dreams. Theresa dreams to realize her potentials and become a career woman. Helen dreams of romance and life of American middle class housewives. In the pursuit of their separate dreams, both Helen and Theresa accept some of the American values and they gradually change their views on marriage. They desire and struggle to establish much more equal relationship with men. Helen and Theresa show their intelligence and determination in work, though one deals with the housework and the other has a professional job. The change of Helen and Theresa's dreams reflects the change of their values. Internalizing the American cultural values, Helen and Theresa become 
independent and strong American women who bravely pursue their happiness and make decisions for their own lives.

\section{Dream of Social Acknowledgement: From “Sojourners” to “Typical Americans”}

Gish Jen tells her readers at the very beginning of Typical American that "[i]t's an American story" (Jen, 1991, p. 3), positioning the identities of the Changs as Americans, or "typical Americans" as the name of her book signifies. The Changs, however, do not become "typical Americans" as soon as they settle down in America. Their cultural identities undergo constant transformation in their gradual assimilation into the mainstream society. According to Stuart Hall, cultural identity is “a matter of 'becoming' as well as of 'being'” (Fregoso, 1993, p. $665)$.

[Cultural Identity] belongs to the future as much as to the past. It is not something that exists, transcending place, time, history and culture. Cultural identities come from somewhere, have histories. But like everything which is historical, they undergo constant transformation. (Fregoso, 1993, p. 665)

The Changs gradually change from the "sojourners" to American citizens as they have different choices of residence (Siu, 1952, p. 34). During their early days in America, the Changs live in the shabby oversea students' apartment as "sojourners" who refuse to become American citizens (Siu, 1952, p. 34). Even after they become permanent citizens, they adhere to Chinese cultural values and view the Americans from outsiders' perspective. Later they move into a larger apartment in Washington Heights. They gradually accept the American values and become aware of their ignorance of America. After they move into a new split-level house in the white neighborhood and become American citizens, the Changs idealize America as a paradise where they believe they can realize all their dreams. With the bankruptcy of their fried chicken restaurant, the Changs have to sell their split-level house. They wake up from their fantasy of America. With their moving into a garden apartment, the Changs have a better understanding of the meanings of being Americans. They also become aware of the limits of the American Dream. This chapter attempts to illustrate how the Changs change from the "sojourners" to American citizens through analyzing their choices of residence (Siu, 1952, p. 34).

At the very beginning, the Changs live as Chinese "sojourners" in America as they do not plan to settle down in this country. The "sojourner" is one who "clings to the cultural heritage of his own ethnic group and tends to live in isolation, hindering his assimilation to the society in which he resides" (Siu, 1952, p. 34). During their early days in America, the Changs live in oversea students' apartments equipped with simple facilities. They adhere to Chinese values and behave in Chinese way. According to Siu, the sojourners usually immigrate to another country for "a religious mission, a commercial interest, an economic adventure... [or] an academic degree” (Siu, 1952, p. 35). The "sojourners” usually conceive their sojourn as "a 'job” which is to be finished in the shortest possible time” (Siu, 1952, p. 35). The reason that Ralph comes to America is to get a Ph. D. degree. He plans to go back to China after he obtains his degree. He has to change his plan after the communists take power and great changes take place in China in 1949. At that time a great deal of Chinese students including Ralph are detained by the United States. Scared by the propaganda of American government, Ralph dreads that if he goes back to China he may be put into prison or killed by the communists. There is nothing that Ralph can do but to make preparations for settling down in America. However, Ralph refuses "to be made an American citizen” (Jen, 1991, p. 23). He still positions himself as a Chinese oversea student who is just temporarily staying 
in America, or a Chinese sojourner in America.

Helen and Theresa, during their early years in America, do not plan to remain in America for the rest of their life. They are sent abroad by their parents to keep away from the political turbulence in China. For them, America then is just a harbor where they can stay away from the wars in China. During the early days in the United States, Helen firmly adheres to the Chinese habits of eating, dressing and speaking. She learns to cook so that she can have Chinese food to eat. She does not eat when she can not have Chinese food. She worries that she may wear out her "irreplaceable clothes" she brings from China (Jen, 1991, p. 62). She walks as little and as slightly as she can to "spar[e] her shoes" so that they will "last until the Nationalists sav[e] the country and she c[an] go home again” (Jen, 1991, p. 62). She believes that she is just temporarily staying in America, so she considers it unnecessary for her to "struggle with [her] English" (Jen, 1991, p. 62). She studies lightly and even spends the class time in writing to her parents. The reason that Helen keeps her Chinese habits is that she still considers herself as a Chinese and thinks that she will go back to China one day.

After Ralph and Helen get married, the Changs move into a shabby apartment north of 125th Street where the air "smell[s] of mildew and dog" and "the poorest of students liv[e]" (Jen, 1991, p. 65). Depending on Ralph's Ph. D. scholarship, the Changs make a poor living. The apartment that they rent is in a miserable condition. On the wall of their bedroom, there is a crack which is getting bigger and bigger. Their ceiling is also in a bad condition as it often leaks when it rains or snows heavily. Helen has to scatter various containers on the floor to catch the leaking water in stormy weather. She once "count[s] thirteen containers scattered around the apartment, each with its own rhythm and pitch” (Jen, 1991, p. 75). The location of their apartment which is far away from the white neighborhood symbolizes the marginalized position of the Chang family in American society. Confining themselves in a very small circle of sociality, the Changs seldom take part in any social activities which may help them know more about the Americans. The Changs are actually much isolated from the American mainstream society at that time.

Not before long, the Changs become permanent citizens, but they adhere to their Chinese identity and view the other Americans from the outsiders' perspective. They do not consider themselves as Americans though they have become permanent citizens in America. What they identify at that time is still traditional Chinese cultural values. They view the Americans around them in Chinese perspective whom they ridicule as "typical Americans" and good-for-nothing (Jen, 1991, p. 67). Pete, who always fails to fulfill his duties as the super in the apartment that the Changs live, is one of the few white Americans that the Changs know during their early days in America. In the Changs' eyes, Pete always behaves weirdly. They mock him as “typical American” and play various jokes on him in their leisure time. Ralph even mimicks Pete's awkward gait and calls him a Fan tong (rice barrel) at which Theresa and Helen can not help laughing. Gradually, "typical Pete” is replaced by "typical American” which becomes a substitution for the Changs to name all the other Americans. Being critical about the behavior of the Americans that around them, the Changs always "sh[ake] their heads over" the American way of doing things which they consider as unintelligible (Jen, 1991, p. 67).

“Typical American no-good,” Ralph would say; Theresa, “typical American don't-know-how-to-get-along”; and Helen, wistfully, “typical Americans just-want-to-be-the-center-of-things.” They were sure, of course, that they wouldn't "become wild” here in America, where there was “no one to control them”. (Jen, 1991, p. 67) 
The Changs' mocking attitude toward the other Americans indicates that they refuse to identify with the American values. The Changs have a strong feeling of alienation from America and the "typical Americans" (CHENG, 2003, p. 67).

After Ralph and Theresa get their Ph. D. degrees, the Changs move into a new and larger apartment that Helen finds in Washington Heights. Ralph obtains a teaching post in a university. Theresa becomes a doctor in a hospital working side by side with the white Americans. With an improvement in their income, the Changs are able to afford to rent a much better apartment. Helen is happy because in rainy days she will no longer worry about the ceilings to leak. What's more, there is a room for Mona and Callie, and there is also a dining room that can be made into a room for Theresa. By then, the Changs have been settling down in America for nine years. They have advanced from permanent residents to American citizens. They finally have the feeling of "truly settled" which is still "a novelty" to them (Jen, 1991, p. 124). With the improvement of their living condition, the whole family is immersed in happiness and every day they find that they wake up with "a sense of purpose” (Jen, 1991, p. 124). They cherish great hope toward their life which Ralph believes "going up” every day (Jen, 1991, p. 124). No longer confining themselves in their small world, the Changs begin to take part in some outdoor activities. They occasionally go to see movies or play some ball games.

With their moving into this new apartment, the Changs become more and more Americanized as they have accustomed themselves to American life in many aspects. They celebrate Christmas as well as Chinese New Year. They are "regulars at Radio City Music Hall” (Jen, 1991, p. 123). Ralph has a Davy Crockett hat, and Helen knows "most of the words to most of the songs in The King and I, and South Pacific" though she still habitually "inquire[s] of people if they [have] eaten yet" (Jen, 1991, p. 123). At home, they use both Chinese and English in their daily life, "slipp[ing] from tongue to tongue like turtles taking to land, taking to sea” (Jen, 1991, p. 124). They have become to some extent the "typical Americans" at whose behavior they used to laugh. When Ralph suggests buying a car, Theresa plays joke on him by calling him “one-hundred-percent Americanized” (Jen, 1991, p. 128). Though Ralph does not want to admit that he is in many ways Americanized, he and Helen agree to make their two daughters Americans. The relationship among the Chang family members is also much Americanized. Ralph used to pose himself as the father of the whole family who "c[an] do whatever he like[s]" (Jen, 1991, p. 113). However, living in this bigger apartment, he becomes tolerant and nice especially after he becomes an associate professor. He becomes a much friendly father who plays with her little daughters. When Mona and Callie "clim[b] over him and pul[1] at his fingers, his nose, his ears, as if to take them for their own", Ralph laughs with his “jaw agape” (Jen, 1991, p. 125).

Though the Changs gradually identify with their identity as American citizens, they realize that the other Americans still refuse to accept them as Americans. Immersed in unprecedented happiness, the Changs name themselves as "Chang-kees"- short for the "Chinese Yankees" (Jen, 1991, p. 127). Yankees is the name of a baseball team which is the favorite of the Changs. Once, the Changs go to an actual game between Yankees and another team, hoping to cheer up for Yankees. However, the other spectators "cal[1] them names and t[ell] them to go back to their laundry" (Jen, 1991, p. 127). Humiliated, the Changs "s[i]t impassive as the scoreboard” (Jen, 1991, p. 128).

Moving into a new split-level house which is located in the white neighborhood symbolizes the Changs' assimilation into the American mainstream. Apparently, this new house is much better than any apartment that 
they used to live in. When they live in the apartment in Washington Heights, the dining room has to be made into Theresa's room. However, this new house is enormous enough to afford three bedrooms for the Changs. They do not need to change the dining room into a bedroom any more. Each one gets his or her proper place. Ralph has a study room while Theresa has a bedroom; the children have their playroom while Helen has her favorite kitchen.

In this big house, Helen realizes her dream as an American housewife. Believing that "a top-quality family [i]s growing out of top-quality house" (Jen, 1991, p. 159), Helen finds that the house seems to have "drawn out of the family roomfuls of activity” (Jen, 1991, p. 160). Obviously, the big house brings great changes to the Changs' life. Each one of them feels comfortable and relaxed.

Helen had never seen the children run so much, touch so much, shout so much. They did not contain themselves. Why should they? Theresa talked to herself, Helen noticed, sometimes loudly; Ralph swung his arms around when he walked, sprawled when he sat. Even his papers had begun to proliferate. As for herself, she'd begun leaving the radio on all day, and cooking big complicated meals involving multiple bowls. (Jen, 1991, p. 160)

Helen even finds that she "breathe[s] more" in this new house (Jen, 1991, p. 160). Her passion as a housewife is evoked as she finds herself much more interested in cooking. She furnishes her new house in the American way which she learns from the advertisements in the newspapers. She learns to plant grass on the lawn in front of their house.

Living in the white neighborhood, the Changs communicate more with white Americans, assimilating quickly into the mainstream society. After they move into the new house, the Changs find for the first time that they have so many white American neighbors most of whom belong to the American middle class. They are no longer the Changs who used to confine themselves in their small world. They get to know their American neighbors when they start to plant grass on their lawn. One month after they move into their new house, Helen begins playing bridge with her American neighbors.

It seems that moving into the new house enables the Changs to review America and Americans from a different perspective. Though still curious about the behavior of the other Americans, the Changs no longer despise them. Living in the new house, the Changs believe that their life is "radiant with truth and discovery" while their former life "s[inks] in the black muck of ignorance" (Jen, 1991, p. 158). They realize that it is because of their ignorance that they sneere at the "typical Americans” as good-for-nothing (Jen, 1991, p. 67). Being aware of their ignorance, the Changs find that they know very little about America and Americans indeed. Completely identifying with their American identity, the Changs feel proud of being American citizens.

Immersed in happiness and excitement in their new life, the Changs idealize America as a paradise where they believe they can realize all their dreams. Having owned a car and a new house, the Changs live like every other American middle class. It seems to the Changs that the land that they used to live in is a "mere offshore land" whereas the present new world that they live in is "a [big] continent” (Jen, 1991, p. 158). America has become a paradise for the Changs where "[e]very dream come dreamily true” (Jen, 1991, p. 158). The Changs even consider that everything is in high quality in America even the soil. The whole family is absorbed in Helen's project of growing grass in their lawn. When the grass finally comes out of the earth they can not help praising the “top-quality” of the American soil (Jen, 1991, p. 159). They even compare the American soil with the Chinese soil which they now consider much barren than that of the America.

The Changs' fantasy of America as a paradise finally collapses with the coming of a series of family 
tragedies. A big crack appears on the wall of Ralph's restaurant. Though he bestows all of his money and hope in this restaurant, it finally goes bankruptcy. Knowing that Grover traps him by selling him the "unstable and unbuildable land" on which he builds his restaurant, Ralph regrets deeply that he has trusted this vicious man (Jen, 1991, p. 244). He can do nothing to Grover since the procedure of their cooperation is illegal and he is unable to claim any compensation from Grover. What strikes Ralph furthermore is his learning about Helen's affair with Grover. Driving in an angry mood, Ralph accidentally hits Theresa badly. Hanging in a coma, Theresa becomes an unconscious person. Though the split-level house brings them much happiness, Ralph and Helen have to sell it so as to pay off the debts of running the restaurant and afford the medical expenses for Theresa. A series of family tragedies make the Changs wake up from their former illusion of America as a paradise where they can realize all their dreams easily. They realize that their idealization of America as a paradise is but a fantasy. They also realize that their life is not always "going up" as they imagine (Jen, 1991, p. 124). Theresa's hanging in coma in the hospital also makes the Changs wake up from their used fantasy that death is impossible "in this bright country" (Jen, 1991, p. 286).

The Changs move to a nearby garden apartment after they sell the split-level house. It seems that the Changs have returned to their starting point in America when they are poor and live in the shabby apartment north of 125th Street. However, the misfortunes that happen in succession disintegrate their used fantasy of America as a paradise. The Changs are no longer the original Changs. Waking from their used fantasy of America and the American Dream, the Changs learn to view America from a much more realistic perspective. They realize that America provides them chances to realize their separate dreams and individual values, but they also have to make costly sacrifice to realize their dreams.

Having woken up from their illusion of America, the Changs understand the meaning of being real members of Americans. They know that to be down-to-earth Americans means that they have the opportunity to realize their dreams, but at the same time they have to face the risks and disasters that may come along in the pursuit of their dreams. They also realize that being Americans does not mean that they have to completely give up the Chinese values that they used to stick to. Theresa's hanging in coma in the hospital makes the Changs become aware of the importance of the unity of their family. In the end of the novel, Theresa's waking up from her coma makes Ralph see the prospect of the reunification of the whole family in a near future. He regains faith to live in America. Evolving from the "sojourners" to American citizens, the Changs have a better understanding of America and the American Dream. They also know better the meanings of being Americans. Cherishing their “Chinese American sensibility” (Chin, 1991, p. 18), the Changs become typical Americans.

\section{Conclusion}

Through an analysis of the change of the American dreams that pursued by Ralph, Helen, and Theresa in Jen's Typical American, this thesis illustrates how the Changs change from the Chinese to the Americans.

The Changs adhere to Chinese cultural values when they first arrive in America. As first generation Chinese immigrants, the Changs bear great influences of traditional Chinese culture-Confucianism. Ralph's initial dream of becoming a scholar reflects his inheritance of typical Chinese views on success which considers schooling as an honorable way to success. Helen and Theresa, influenced by "three obediences" and "four virtues", habitually depend on the others especially their family members and seldom have their own desires. 
However, with the change of their lives in America, Ralph, Helen, and Theresa gradually have different American dreams. Ralph dreams to realize his potentials and become a self-made man; Theresa dreams to become a career woman; Helen dreams of romance and the life of American middle class housewives. In the pursuit of their dreams, Ralph accepts the American views on success which consider wealth as the symbol of success; Theresa accepts the American values which encourage people to pursue their true love; Helen is influenced by American consumer culture and becomes an enthusiastic consumer. With the change of their cultural values, the Changs become typical Americans though maybe they are not aware of it.

The Changs have a better understanding of the American Dream and the American society from their own experience of pursuing the American Dream. In the pursuit of their American dreams, Ralph, Helen, and Theresa partly realize their individual values. Ralph knows about his limits. Helen and Theresa grow from obedient Chinese women to independent Americans who have their own desires and dreams. They form an illusion of the America as a paradise where they can easily realize their dreams. They gradually identify with their identities as American citizens. However, the misfortunes that fall on the Changs make them realize that they can not escape from the risks and responsibilities that come along with their dreams. They realize that opportunities and risks coexist when they pursue their dreams. America is not a paradise which provides "[f]reedom and justice for all" (Jen, 1991, p. 183).

The Changs finally wake up from their illusion of America and the American Dream, and they know better the meanings of being Americans. They realize that as Americans, they have the opportunity to pursue their dreams and realize their potentials. However, they also have to face the risks that come along with their dreams. They learn that they do not have to give up completely the Chinese values that they used to stick to. Cherishing their Chinese American sensibilities, the Changs become real Americans.

As Stuart Hall suggests, "cultural identity” is always in a process of "becoming” (Fregoso, 1993, p. 665). The Changs' cultural identities are also in a process of transformation. With the Change of their lives in America, the Changs have different American dreams. In the pursuit of their dreams, they gradually accept the American values that lie behind their dreams, and they transform from the Chinese to typical Americans. As Jen says in one of the interviews, "I wanted to challenge ideas of what a 'typical American' looks like, to put forward the idea that the Changs are not any less American than anyone else" (Matsukawa, 1993, p. 114). By positioning the Changs as "typical Americans", Gish Jen makes her claim that Chinese Americans are authentic Americans.

\section{References}

Adams, J. T. (1931). The epic of America. New York: Blue Ribbon Books.

CAI, Q., \& ZHANG, H.W. (2006). An anlyasis of the housing images in Typical American. Foreign Languages and Their Teaching, (3), 44-45.

CHENG, A. M. (2003). A study of Chinese American literature. Beijing: Peking University Press.

Chin, F. (1991). Aiiieeeee! An anthology of Asian American writers. New York: Penguin Books USA Inc..

Chua, C. L. (1981). Two Chinese versions of the American dreams: The golden mountain in Lin Yu-tang and Maxine Hong Kingston. Melus, 8(4), 61-70.

Cournane, J. (2007). Are rural American Indian adolescents becoming a race of angels? First Peoples Child and Family Review, (3), 127-132.

Crary, C. S. (1959). The humble immigrant and the American dream: Some case histories, 1746-1776. The Mississippi Valley Historical Review, 46, 46-66.

Cullen, J. (2003). The American dream: A short history of an idea that shaped a nation. New York: Oxford Universtity Press. 
Decker, J. L. (1994). Gatsby's pristine dream: The diminishment of the self-made man in the tribal twenties. Novel: A Forum on Fiction (28), 52-71.

Fitzgerald, F. S. (1992). The great Gatsby. New York: Macmillan Publishing Company.

Fregoso, R. L. (1993). The representation of cultural identity in 'Zoot Suit' (1981). Theory and Society, (22), 659-674.

GUAN J. (2006). A holy woman-the combination of Chinese and western cultures-character analysis of Terrisa in Typical American. Journal of Changchun University, (7), 69-71.

HE, W. J., \& SHAN, D. X. (1994). Cultural identities and Chinese American literature. Taibei: Institute of European and American Studies, Academia Sinica.

Huntington, S. P. (2004). Who are we?: The challenges to America's national identity.New York: Simon and Schuster, Inc.

Jen, G. (1991). Typical American. Boston: Houghton Mifflin Company.

Latourette, K. S. (1958). The contribution of the religion of the colonial period to the ideals and life of the United States. The Americas, (14), 340-355.

LI, X. H. (2003). Pursuit and predicament-An analysis of Ralph’s American dream in Typical American. Journal of Zhejiang Normal University: Social Sciences, (6), 23-26.

LIU, D. (2003). Cultural identity and re-conceptualization: A reading of typical American. Chinese Literature, (5), 47-50.

Matsukawa, Y. (1993). Melus interview: Gish Jen. Melus, (18), 111-120.

Pearson, R. L. (1970). Gatsby: False prophet of the American Dream. The English Journal, (59), 638-642, 645.

PU, R. Q. (2006). Ethnic experience and cultural imagination-A Study on the representative motifs of Chinese American novels. Beijing: China Social Sciences Press.

SHAN, D. X. (2006). Self/Ethnicity-Creating: Interview of Gish Jen. Chinese American literature and culture. Tianjin: Nankai Univeristy Press.

SHI, P. P. (2001). Cultural identity in Gish Jen's Typical American. Journal of Nanjing Normal University (Social Science Edition), (4), 120-125.

Siu, P. C. P. (1952). The sojourner. The American Journal of Sociology, (58), 34-44.

University of Minnesota-Driven to Discover (n.d.). Gish Jen. Retrieved from http://voices.cla.umn.edu/artistpages/jenGish.php WANG, Z. (2003). Poems of wonder child. Jinan: Qi Lu Press.

XUE, Y. F. (2003). Typical Chinese in Typical American. Journal of Guangdong University of Foreign Studies, (9), 40-43

ZHU, Y. T. (2002). American values. Beijing: Foreign Language Teaching and Research Press. 